\title{
Editorial
}

\section{Volume 08 Número 02}

O presente volume contém os primeiros trabalhos aceitos para publicação referentes à chamada realizada através do XVI Congresso da Associação Brasileira de Estudos do Quaternário. A chamada redundou em significativo aumento das submissões à revista, pelo que os editores agradecem a Comissão Organizadora do Congresso.

Os artigos foram e continuam sendo avaliados por parecerias ad hoc, e serão publicados na sequencia de sua aprovação, nas respectivas seções temáticas.

Rodolfo José Angulo

Editor-Chefe 